\title{
The Effectiveness of Implementation Warmer Apperception to Construct the Conceptual Understanding on the Learning Material of Vector
}

\author{
Riska Nur Rohmah, Dwi Priyo Utomo, Zukhrufurrohmah
}

\author{
Study Program of Mathematics Education, Faculty of Teacher Training and Education, \\ University of Muhammadiyah Malang \\ RiskaNurRohmah28@gmail.com
}

\begin{abstract}
One of the learning stages is apperception. Warmer apperception is an activity that conducted to make the students' knowledge to be stored in long-term memory. This research aimed at: 1) describing the learning implementation using Warmer apperception to construct a conceptual understanding in the vector material, 2) determining the effectiveness of the implementation of Warmer apperception to construct a conceptual understanding in the vector material. The effectiveness of learning using Warmer apperception could be seen from: 1) the observation of learning implementation using Warmer apperception that indicated a minimum of the sufficient category; 2) the students' response questionnaire indicated a minimum of positive response category; and 3) the test results of students' conceptual understanding indicated a minimum of quite a good category. The subjects of this research were the students of 10th grade of Mathematics and Natural Science (MIA) at Senior High School (SMA) of Muhammadiyah 3 Batu, in which it consisted of 21 students. Based on the research conducted, it was obtained that the observation results of learning implementation using Warmer apperception got a very good category, the questionnaire results obtained a positive response category, and the test results of students' conceptual understanding got a quite good category. Thus, the implementation of Warmer apperception to construct a conceptual understanding of the vector material is effective.
\end{abstract}

Keywords: Effectiveness of Warmer Apperception, Warmer Apperception, Conceptual Understanding.

\section{INTRODUCTION}

Conceptual understanding is an ability that relates to an understanding of the overall mathematical thinking (Fahrudhin et al., 2018). However, Annajmi (2016) asserts that the students' conceptual understanding ability at this time has not shown a good conceptual understanding. As for choosing appropriate learning, it can improve the students' conceptual understanding ability. One of the learning stages is apperception. At the beginning of learning activities rarely implemented the apperception activities (introduction to facilitate in the understanding of the material by connecting the experiences or students' conceptual that already owned by the students) (Wijaya, 2015). According to Herbart's concept (in Saifudin, 2015), learning by using an implementation of apperception will also help the students in logical, systematic, and structural understanding. There are several sources of learning apperception that can be implemented include of Warmer Apperception. Warmer is an activity that conducted to make knowledge to be stored in long-term memory (Ulfiyani, 2017). The students need to have participated in the directed question and answer process and the search for solutions to various learning problems (Marsantika \& Zulfajrin, 2017). Through the 
background explanation of the problem, the researcher takes the research problems regarding how the learning implementation and the effectiveness of the implementation of Warmer apperception to construct the conceptual understanding of in learning especially on the vector material. The research objectives expected from this research are to describe and determine the effectiveness of the implementation of learning using Warmer apperception to construct the conceptual understanding of the vector material.

Mathematical learning is a process of activities carried out by the teacher to the students in certain conditions to understand a concept so that it is easier to learn and implement it to real situations. According to Government Regulation of Education and Culture on the Standard Process for Primary and Secondary Education Unit No. 22 of 2016 explains that the implementation of Lesson Plan (RPP) includes preliminary, main, and closing activities. In the preliminary activities, the teacher can do an apperception. Ningsih (2013) reveals that apperception is carried out in the preliminary learning activities between 5 to 10 minutes. Then, according to Nasution (in Marisatunniyyah, 2016), there are several teacher guidelines in the implementation of apperception, namely: 1) distribution of brief information about the material to be carried out, 2) repetition of the material that has been carried out, 3) exposure to the relevance of the material to be carried out; 4) connecting the previous material with the material to be carried out.

The activities of Warmer apperception are carried out by giving questions of games and self-assessment. The Warmer apperception indicators used in this research are: 1) delivering a brief information about the material to be studied, 2) explaining/ stimulating the students with phenomena or questions according to the material to be studied, 3) providing chances between students to give responses for each answer, 4) responding to the students' answers, 5) inserting an explanation of prerequisite material a review, and 6) providing and explaining the use of self-assessment sheets.

One of the mathematics learning aspects is a concept. According to Sari (2018), who postulates that the conceptual understanding is an ability to absorb the meaning of an abstract idea that can be used to classify the objects, in which those are included or not included in abstract ideas that are learned through the activities of recognizing, explaining, and drawing conclusions. As according to Irwandani \& Rofiah (2015), the conceptual understanding has several indicators, namely: 1) interpreting, 2) exemplifying, 3) classifying, 4) drawing conclusions/inferring, 5) comparing, and 6) explaining. Some indicators of conceptual understanding used in this research are: 1) interpreting, 2) exemplifying, 3) classifying, 4) drawing inference/inferring, and 5) explaining.

The learning that has been implemented is expected to achieve the learning objectives. The learning is stated to be effective when achieving the desired goals so that the indicator of learning effectiveness is the ideal time used by the students to carry out every activity contained in the lesson plan, the ability of teacher to manage the learning and the students' responses toward the positive learning can be achieved (Pardomuan in Erfian, 2011). The effectiveness of Warmer apperception in this research will be seen through the implementation of learning, the students' responses, and the results of the students' conceptual understanding test. The Warmer apperception is said to be effective if the results of observation of the implementation of Warmer apperception show a minimum of the sufficient category, the results of the students' questionnaire responses show a minimum of positive response category, and the results of the students' 
conceptual understanding test of learning using Warmer apperception show a minimum of quite a good category.

The implementation of Warmer apperception to construct the conceptual understanding of this research is by using the vector material. Basic Competencies (KD) of vector material used include of: 1) explaining vector, vector operation, vector length, the angle between vectors in two-dimensional and three-dimension spaces and 2) completing the problems related to the vector problems, vector operation, vector length, angle between vector in two-dimensional space (area) and three-dimensional. While the Basic Competencies' achievement (KD) indicators used include : 1) interpreting the concept of vectors, 2) writing/giving vectors and not-vectors, 3) explaining vector operations on flat area in two-dimensional space (area) and three-dimensional space, 4) determining the results of vector length in two-dimensional space (area) and threedimensional, 5) determine the results of operations of addition, subtraction, and multiplication of vectors in two-dimensional space (area) and three-dimensional, and 6) solving the problems related to the vectors in two-dimensional space (area) and three dimensional space.

\section{RESEARCH METHODS}

This research aimed at determining, describing, and analyzing the effectiveness of the implementation of Warmer apperception to construct the conceptual understanding of the vector material. The type of research chosen was descriptive research. While this research approach used a quantitative approach. This research was conducted in the 10th grade of Mathematics and Natural Science (MIA) at Senior High School (SMA) of Muhammadiyah 3 Batu, in which it consisted of 21 students. The learning process was carried out for three times with a time allocation of $6 \times 40$ minutes. The stages in the implementation of this research were: 1) the preparation stage included the discovery of research problems, the literature study, the determination of the problems to be studied, the making of research instruments, and the implementation of instrument validation; and 2) the implementation stage included of the implementation of Warmer apperception in the 10th grade of Mathematics and Natural Science (MIA) at Senior High School (SMA) of Muhammadiyah 3 Batu, observation on the implementation of Warmer apperception by the observer, students' questionnaire distribution, and conducting the conceptual understanding test of vector material. The analysis used in this research was sourced from the observation of the implementation of Warmer apperception, the students' questionnaire responses, and the test of the students' conceptual understanding ability.

\section{RESULT AND DISCUSSIONS}

The discussion in this chapter described the implementation and determined the effectiveness of learning using Warmer apperception to construct the conceptual understanding on the vector material. Th initial/preliminary activities with Warmer apperception that had been carried out were in the form of questions of games and selfassessment. This research was conducted in three times. The questions of games conducted in this research included of several aspects, namely: 1) delivering the material to be studied, 2) explaining/stimulating the students with phenomena or questions 
according to the material that would be studied, 3) providing a chance between the students to give responses to each other's answers, 4) responding to the students' answers, and 5) inserting an explanation of the prerequisite material as a review. Whereas the self-assessment in this research included of: 1) giving and explaining the use of self-assessment sheets.

\section{The Implementation of Warmer Apperception to Construct a Conceptual Understanding on the Vector Material}

\section{a. The Implementation Description of Warmer Apperception to Construct a Conceptual Understanding on the Vector Material}

At the first meeting, the questions of games were carried out by submitting the material that would be studied. After that, it continued to stimulate the students with phenomena or questions according to the material that would be studied. The stimulus that given was by showing a few pictures about the application of vectors in the surrounding life. The picture was a picture of an archery athlete, a bow athlete, and a picture of a boat that shifted from one land to another by passing a river current. After showing a few pictures, then random questions were given to the students. These questions included of the relationship of images with vector material. The students gave answers to each other related to the three images that had been shown. Then, the teacher responded to the students' answers and inserted an explanation of the material, namely matrix and trigonometry as a review.

It was expressed by the students that through the pictures that had been shown, the understanding of vectors could be better understood clearly. For example, in the picture of archery athletes when pulling a bowstring and preparing to release arrows on the target board, it meant that it had produced a large direction. So, it could be said that the archery activities were activities that implemented vectors. Then, it was explained if the archery athlete's image was a vector, then also the angle could be calculated (including the trigonometric material). The matrix material was also not free from the explanation of the review. The use of matrix material was found in the writing of vector components. In the archery athlete's image, a matrix was written for vector writing from the direction of the archery (vector base) to the target board (vector end).

At the first meeting, it was also given and explained the use of self-assessment sheets. Based on the contents of the self-assessment sheet given at the first meeting, it could be concluded that the students did not remember and did not understand the matrix material, the students remembered and understood the trigonometric material, and the students knew the vector but did not know what was meant by the length of the vector.

At the second meeting, the questions of games that were carried out were preceded by the delivery of material that would be studied by the teacher. Then, stimulated the students with questions according to the material to be studied. These questions included of "Could a vector be operated with another vector?", "How to calculate the angle between two vectors?". Then, the teacher gave a chance between the students to respond to each other's answers. This activity was carried out by appointing the students randomly, continuing with the student appointed to another friend to get the right answer or almost approached to the right answer. The teacher then responded to the students' answers. The teacher also inserted an explanation pf the prerequisite material as a review at the first meeting (understanding vectors, vector notations, examples and notexamples of vector, drawing the vectors) and initial understanding of the multiplication of vectors in two-dimensional (area) and three-dimensional spaces. 
It was not different to the first meeting, at the second meeting was also given and explained the use of self-assessment sheets. Based on the contents of the self-assessment sheet given at the second meeting, it could be concluded that the students were able to explain and determine the length of the vector, but they were unable to explain and determine the material of vector operations.

At the third meeting, the question of games that were carried out were started with the delivery of material that would be studied. Then, the teacher gave stimulus to the students with questions about the material that would be studied as well as explanation of prerequisite material as a review. The stimulus was given by doing the game of applause. If the students did not clap in accordance with the direction given, then the students were required to answer the questions related to the review of the material at the second meeting (multiplication of vector in two-dimensional space and three dimensional space) and an initial understanding of the vector operation material on a geometrical plane in two-dimensional (area) and the three dimensional space. It was stated to clap one, then the students did the clap one. It was said clap two, then the students did the clap two. It was said clap three, then the students did the clap three. It was said clap of one package, then the students did in sequence one time of clap, two times of clap, and three times of clap. The direction given would be said quickly, so that the students who did not pay attention would surely make a clap. If the clap was wrong, the students were required to answer the questions given. Through this question and answer, the students were given a chance to respond to each other's answers and the teacher gave feedback.

At the third meeting, it was also given and explained the use of self-assessment sheets. Through the self-assessment sheets, it could be concluded that the students had understood the matrix material, understood the length of the matrix, understood the vector operations, and were able to determine the value of a vector operation.

Based on the observation of the implementation of Warmer apperception during three meetings in the $10^{\text {th }}$ grade of Mathematics and Natural Science (MIA) at Senior High School (SMA) of Muhammadiyah 3 Batu would be explained as follow. At the first meeting, the percentage of scores obtained from the two observers were $89.58 \%$ in the good category. But there were things that needed to be observed from the six aspects of Warmer apperception, in which it was the delivery of the material that would be studied; moreover, it was still obtained a score of 3 from both observers. This was due to the lack of explanation of the material provided by the researcher. Although the availability of a handout had included the concept of the material, but the delivery of the material still needed to be specified to increase the students' conceptual understanding.

At the second meeting, the percentage scores obtained from the two observers were $91.67 \%$ which was in the very good category. Despite an increase, one aspect of the implementation of Warmer apperception was the aspect of giving and explaining the use of self-assessment sheets, in which it still got scores of 3 from both observers. The use of self-assessment sheets which were still rarely done by the students made the researcher had to explain in detail so that it required an additional time. This would certainly be the subject of future evaluations regarding to the use of self-assessment sheets to support the implementation of Warmer apperception.

After implementing the Warmer apperception at the first meeting and the second meeting, at this third meeting, the percentage scores obtained from the two observers increased to $93.75 \%$ with a very good category. The average scores of the two observers at this third meeting got a score of 4 . As for the average percentage of all meetings from 
observations of the implementation of Warmer apperception obtained a score of $91.67 \%$ with a very good category. The meaning of this very good category showed that the indicators or aspects (questions of games and self-assessment) of Warmer apperception were done very well.

\section{b. The Results of Students' Response Questionnaire to the Implementation of Warmer Apperception to Construct a Conceptual Understanding on the Vector Material}

The data of the students' responses to the implementation of the Warmer apperception that carried out was obtained through a questionnaire that was distributed at the end of the third meeting. From the total number of students in the $10^{\text {th }}$ grade of Mathematics and Natural Science (MIA) at Senior High School (SMA) of Muhammadiyah 3 Batu, there were 21 students, but only 17 students who could fill out a questionnaire because 4 other students did not attend to the school. There were 26 statements on the students' response questionnaire sheets containing 4 aspect indicators with 13 positive statements and 13 negative statements.

Based on the results of the students' response questionnaire above, the indicators of interest and motivation for mathematics lessons using Warmer apperception described through 10 statements obtained total sum 538 and the average students' response reached to 2,56. Hence, this response indicator was included in the positive response category. The meaning of this positive response category indicated that the students had good interest and motivation toward mathematics by implementing the Warmer apperception. This was in line with Apriyanto's research (2014), which stated that the research conducted also showed that there were differences in influence between the Alfa Zone apperception using Scene Setting to the motivation learning of Natural Science (IPA) in the $4^{\text {th }}$ grade students of SDTA MTA of Gemolong Sragen on 2014/2015. The indicator of usefulness in learning mathematics through Warmer apperception which was described through 2 statements obtained the number of 108 and the average students' response reached to 2,57. Thus, this response indicator was included in the positive response category. The meaning of this positive response category showed that the students understood well the usefulness of mathematics learning through the implementation of Warmer apperception.

The indicator of conceptual understanding using Warmer apperception that described in 8 statements obtained a total of 435 and the average students' response reached to 2,59. Hence, this response indicator was included in the positive response category. The meaning of this positive response category indicated that the students understood well the concept of implementation of Warmer apperception. The indicator of working on the test of conceptual understanding using Warmer apperception which described through 6 statements obtained total sum 326 and the average students' response reached to 2,59. So, this response indicator was included in the positive response category. The meaning of this positive response category indicated that the students could do a conceptual understanding test well from the implementation of Warmer apperception. As for the overall indicators, the number of 1407 were obtained and the average students' response reached 2,57 so that it was included in the positive response category. The meaning of this positive response category indicated that the implementation of Warmer apperception could increase the interest and motivation, increase the knowledge about the usefulness of mathematics and students' conceptual understanding of the material. 


\section{c. The Test Results of Students' Conceptual Understanding}

After carrying out the Warmer apperception, the researcher conducted a test to find out the students' conceptual understanding on the vector material. The test was given at the third meeting with a total of 5 questions. Based on the results of the conceptual understanding test that had been carried out, it could be concluded that 13 students out of 17 total number of students got a value of more than 55. Thus, the acquisition of the percentage of students with a minimum of conceptual understanding was categorized as quite good, in which it was 76,47. As for the percentage of 76,47, the learning based on the students' conceptual understanding test using Warmer apperception was effective.

\section{The Effectiveness of Implementation of Warmer Apperception to Construct a Conceptual Understanding on the Vector Material}

The effectiveness of this research could be seen from: 1) the implementation of learning using Warmer apperception, 2) the students' responses to the learning, and 3) the students' conceptual understanding. The implementation of learning using Warmer apperception was seen from the results of observation. The students' responses to the learning could be seen from the questionnaire that would be given. While the students' conceptual understanding would be seen from the test that would be given on the vector material. The Warmer apperception was said to be effective if the results of observation of the implementation of Warmer apperception showed a minimum of the sufficient category, the results of the students' questionnaire responses showed a minimum of the positive response category and the results of the students' conceptual understanding test of learning using Warmer apperception showed a minimum of quite good category. As for the results of the study, it was found that the results of observation of the implementation of Warmer apperception obtained a very good category, the questionnaire results obtained good category, and the results of the students' conceptual understanding test received a good category. So, it was said that the implementation of the Warmer apperception to construct the conceptual understanding in the learning of vector material was effective. The effectiveness of apperception in learning was also stated in the research conducted by of Musliman \& Hamidah (2008) which explained that "Generate" as an apperception of physics learning was quite effective and had become one of the alternative methods or strategies for physics learning specifically for female students at Senior High School (SMA) of Avicenna Cinere. In addition, there was also a research from Marisatunniyyah (2016), which revealed that the apperception activities through songs were more effective on learning outcomes of fiqih subject matter of $d h i k r$ and prayer in the students of $2^{\text {nd }}$ grade of Islamic Primary School (MI) of Matholiul Huda Damarwulan Keling Jepara.

\section{CONCLUSION}

Based on the research implementation, it can be concluded as follows: 1) the implementation of learning using Warmer apperception to construct the conceptual understanding on the vector material can run of by following the lesson plan $(R P P)$; and 2 ) the observation results of the implementation of Warmer apperception obtained a very good category, the questionnaire results obtain a good category, and the results of the students' conceptual understanding test receive a good category. Then, it is found that the 
implementation of Warmer apperception to construct the mathematical conceptual understanding in the learning on the vector material is effective.

The learning by implementing the Warmer apperception to construct the conceptual understanding in the learning of vector material can be used as a first step to help the learning design. However, based on the experience of the researcher during the research, there are a few suggestions that need to be considered, namely: 1) the teacher creativity is needed in conducting the questions of game so that the students do not get bored while the learning; 2) the distribution of the use explanation of detailed selfassessment sheets; and 3) the time allocation arrangements provided for the implementation of Warmer apperception.

\section{REFERENCES}

Annajmi. (2016). Peningkatan Kemampuan Pemahaman Konsep Matematik Siswa SMP Melalui Metode Penemuan Terbimbing Berbantuan Software Geogebra. Jurnal MES, 1-9.

Apriyanto. 2014. Studi Komparasi Penggunaan Alfa Zone dengan Scene Setting Terhadap Motivasi Belajar Muatan IPA Siswa Kelas IV SDIT MTA Gemolong Sragen Tahun 2014/2015. Skripsi S1 Pendidikan. Universitas Muhammadiyah Surakarta.

Arikunto, S. (2006). Prosedur Penelitian, Suatu Pendekatan Praktik. Jakarta: Rineka Cipta.

Asbiyati, F., Murboyono, R., \& Arpizal. (2018, Agustus). Efektivitas Model Pembelajaran Numbered Heads Together terhadap Pemahaman Konsep pada Mata Pelajaran Ekonomi di SMAN 6 Kota Jambi. Repository Universitas Jambi, pp. 2-21.

Dzilhijjah, S. P. (2016). Implementasi Pembelajaran Berbasis Multiple Intelligences pada Siswa Kelas Iii Di SD Jogja Green School. Jurnal Pendidikan Guru Sekolah Dasar.

Erfian, Rahman. 2011. Komparasi Efektifitas Pembelajaran Kooperatif Tipe Numbered Head Together (NHT) dengan Pembelajaran Konvensional terhadap Hasil Belajar pada Mata Pelajaran Akuntansi Siswa Kelas XI IS SMA Negeri 14 Semarang. Skripsi S1 Pendidikan Ekonomi. Universitas Negeri Semarang.

Evi, S. (2011). Pendekatan Matematika Realistik (PMR) untuk Meningkatkan Kemampuan Berpikir Siswa di Tingkat Sekolah Dasar. (pp. 79-85). Bandung: Portal Jurnal Universitas Pendidikan Indonesia.

Fahrudhin, A. G., Zuliana, E., \& Bintoro, H. S. (2018). Peningkatan Pemahaman Konsep Matematika Melalui Realistic Mathematic Education Berbantu Alat Peraga BONGPAS. Jurnal Ilmiah Pendidikan Matematika, 15-20.

Fitri, R. (2014). Penerapan Strategi The Firing Line Pada Pembelajaran Matematika Siswa Kelas XI IPS SMA Negeri 1 Batipuh. Jurnal Pendidikan Matematika.

Gazali, R. Y. (2016). Pembelajaran Matematika yang Bermakna. Jurnal Pendidikan Matematika. Hakim, S. (2014). Peningkatan Hasil Belajar Matematika Melalui Model Pembelajaran Kooperatif Tipe Jigsaw. Jurnal Nalar Pendidikan, 237-246.

Irwandani, \& Rofiah, S. (2015). Pengaruh Model Pembelajaran Generatif Terhadap Pemahaman Konsep Fisika Pokok Bahasan Bunyi Peserta Didik Mts Al-Hikmah Bandar Lampung. Jurnal Ilmiah Pendidikan Fisika Al-BiRuNi, 165-177.

Marisatunniyyah. 2016. Efektifitas Kegiatan Apersepsi Melalui Lagu Terhadap Hasil Belajar Peserta Didik Mata Pelajaran Fiqih Materi Pokok Zikir Dan Doa Kelas 2 MI Matholiul Huda Damarwulan Keling Jepara Tahun Ajaran 2015/2016. Skripsi S1 Pendidikan. Universitas Islam Negeri Walisongo. 
Marsantika, \& Zulfajri, M. (2017). Efektivitas Peningkatan Pemahaman Siswa Terhadap Materi Sistem Koloid dengan Menggunakan Model Pembelajaran Partner Switch. Jurnal Edukasi Kimia, 72-78.

Murizal, A. (2012). Pemahaman Konsep Matematis dan Model Pembelajaran Quantum. Jurnal Edukasi dan Penelitian Matematika.

Mushawwir, M. A., \& Umar, F. (2014). Studi Tentang keterampilan guru dalam melaksanakan pembelajaran PPKn di SMP Negeri 1 dan SMP Negeri 2 Benteng Kabupaten kepulauan Selayar. Jurnal Pemikir, Penelitian Hukum dan Pendidikan Pancasila dan Kewarganegaraan, 124-137.

Ningsih, Mastuti, S. E., \& Aminuyati. (2013). Perbedaan Pengaruh Pemberian Apersepsi Terhadap Kesiapan Belajar Siswa Mata Pelajaran IPS Kelas VII A. Jurnal Pendidikan dan Pembelajaran.

Nurcahyo, J., \& Munadi, S. (2014). Pengaruh Apersepsi Visual dan Minat Belajar Siswa Terhadap Prestasi Belajar Siswa pada Mata Pelajaran Teori Proses Pembubutan Dasar di SMK N 2 Pengasih Kulon Progo. E-Jurnal Pendidikan Teknik Mesin, 31-36.

Peningkatan Pemahaman Konsep Matematika Melalui Realistic Mathematic Education Berbantu Alat Peraga BONGPAS. (n.d.). Jurnal Ilmiah Pendidikan Matematika.

Priyambodo, S. (2016). Peningkatan kemampuan Pemahaman Konsep Matematis Siswa dengan Metode Pembelajaran Personalized System of Instruction. Jurnal Pendidikan Matematika STKIP Garut, 10-17.

Rengganis, Willy. "Kemampuan Pemahaman Konsep Geometri Siswa Kelas VII Antara Pembelajaran Model NHT dan Make A Match". Skripsi S1 Pendidikan. Universitas Negeri Semarang

Rohaeti, E. E. (2012). Analisis Pembelajaran Konsep Esensial Matematika Sekolah Menengah Melalui Pendekatan Kontekstual Socrates. Jurnal Ilmiah Program Studi Matematika STKIP Siliwangi Bandung, 186-191.

Rohmawati, A. (2015). Efektivitas Pembelajaran. Jurnal Pendidikan Usia Dini, 15-32.

Saifudin, M. F. (2015). Optimalisasi Apersepsi Pembelajaran Melalui Folklor Sebagai Upaya Pembentukan Karakter Siswa Sekolah Dasar. Prosiding Seminar Nasional dan Call for Papers Aktualisasi Bimbingan dan Konseling pada Pendidikan Dasar Menuju Peserta Didik yang Berkarakter (pp. 180-185). Surakarta: PGSD Universitas Muhammadiyah Surakarta.

Sari, E. F. (2017). Pengaruh Kemampuan Pemahaman Konsep Matematika Mahasiswa Melalui Metode Pembelajaran Learning Starts With A Question. Jurnal Mosharafa.

Sari, Yulia Purnama. 2018. Meningkatkan Pemahaman Konsep Matematika Menggunakan Pendekatan Realistic Mathematics Education (RME) di kelas V C SDN No. 80/I Muara Bulian. Skripsi S1 Pendidikan. Universitas Jambi.

Situmorang, A. S. (2016). Efektivitas Strategi Pembelajaran Ekspositori Terhadap Pemahaman Konsep Matematika Mahasiswa Prodi Pendidikan Matematika Universitas HKBP Nommensen. Jurnal Suluh Pendidikan FKIP-UHN, 109-119.

Ulfiyani, S. (2017). Karakteristik Apersepsi Mahasiswa Progdi PBSI dalam Praktik Magang 3 di SMP N 35 Semarang. Jurnal Ilmiah Pendidikan Dasar.

Wijaya, A. (2015). Penerapan Variasi Kegiatan Apersepsi dan Pembelajaran Interactive Learning untuk Meningkatkan Aktivitas Pembelajaran dan Kemampuan Pronunciation Mahasiswa dalam Mata Kuliah Pronunciation Practice. Jurnal Didaktis, 46-185. 